\title{
GEOGRAPHY SYLLABUS IN THE SECONDARY SCHOOLS OF INDI A: ISSUES AND CHALLENGES
}

\author{
SARFARAZ ALAM \\ Banaras Hindu University, Institute of Science, Department of Geography, Va ranasi, Uttar Pradesh, \\ India, e-mail: sarfarazalam05@gmail.com
}

(Received: August 2020; in revised form: November 2020)

\begin{abstract}
Constructing the syllabus of a school subject could be a highly contested exercise given the fact that it must cater for the concerns of competing stakeholders and pressures to incorporate all possible aspects of that discipline. For geography, whose field of study is extremely vast, and its nature is not clearly defined, developing its syllabus is particularly challenging. This paper discusses some key issues concerning the status of the geography syllabus in the secondary schools in India. The central theme of the paper is built on the study of documentary sources, research works, as well as on the survey of schoolteachers and geography experts from some school boards. The paper concludes that the educational value of school geography can only be realized by incorporating both physical and human aspects of the Earth in the syllabus.
\end{abstract}

Keywords: geography education, school curriculum, social science, geographical skills, geogaphical values

\section{NTRODUCTI ON}

The syllabus of a school subject is quite crucial from the point of view of teaching and learning of a subject in schools, colleges, and universities. At the same time, the syllabus structure of a school subject depends on the geographical and socio-economic context within which curriculum and textbooks are developed. Long and Roberson (1966, p. 267) define the syllabus as an abstract giving the headings or main objects for a course of teaching, a conspectus or programme of work hours. The syllabus helps teachers and students to prioritise the teaching and learning processes within the ambit of the curricular objectives of a discipline. However, given the vast field of study and "geography curricula in school being devoid of theoretical, methodological and philosophical bases" (Geography and You, 2014), its syllabus construction could be a highly contested exercise. 
Therefore, curriculum developers have created some basic principles for syllabus development. Long and Roberson (1966, p. 267) have identified four basic principles which should be used in the course of the construction of a sound geography syllabus. First, it is important to bear in mind why geography is being taught in school. The reason for teaching geography may vary with individual teachers. It may also vary with the ideological orientation of the state and the society in which the school operates. Second, the geography syllabus should be based on the child's psychological development. Third, as far as possible, the syllabus should include all aspects of geography to get a holistic picture of the subject. In this regard, some consideration of the available teaching time is a necessity. Finally, the syllabus for each grade should be devised to build on the foundations of the previous work and to maintain a steady growth of the subject according to the development of the child's mind.

The Geography syllabus for various levels of school education can be organized either content-wise or objective-wise. However, whether the content or objective-based definition of a discipline is used, the syllabus must be logically organized across different education levels according to the basic principles of education (i.e. suitably placing of subject matters to be taught or curricular objectives to be achieved at different stages of education). Besides, syllabus construction must be a dynamic process. It must change with the changing requirements of the society, as well as with the changing nature of the discipline.

The type of geography syllabus that is taught at different levels in the education system is closely tied to the way the discipline is defined and valued in school curricula from the point of view of its academic and societal significance. For example, if such a definition of the discipline is based on the premise of geography as an Earth science, then components of physical geography dominate the syllabus. In contrast, if the definition of geography is based on the premise of geography as a branch of social science, then components of human geography dominate the school syllabus.

A unique problem faced by geographers in India is that there is no definite ontological posturing of geography in the Indian educational system. Different educational institutions and organizations in India confer different meanings and value to geography as an academic discipline. This creates uncertainty about the precise nature of geography as a discipline as well as its educational purpose. While in schools, it is practiced as a part of social science, in higher education geography has various orientations - as art, social science, science and technology.

As a result, some kind of confusion prevails in the minds of policy makers, academicians, as well as general public, on the precise nature of geography and its educational purpose. These uncertainties are visible in the geography syllabus for Indian schools. Based on primary data, which were collected during 2013-14, the National Curriculum Framework 2005 report, as well as on existing research works on Indian school geography, this paper discusses the main issues and challenges of the geography syllabus in secondary schools in India. 


\section{THE CONTEXT}

The syllabus construction of a discipline could be a highly contested exercise. This is particularly true in the case of geography which encompasses vast subject matter - physical, biotic and human aspects of the earth. The subject makes use of conventional tools as well as modern technologies to describes and interpret the variable character the Earth. It also applies both qualitative and quantitative techniques to represent the Earth. As a result, differences often emerge among curriculum planners on the issue of what should be the core focus of school geography.

The identification of the content of geography education for school is a very challenging task. It is indeed a difficult idea to accept that there is a single corpus of geographical knowledge which should form the basis of geography syllabi of all the schools affiliated to various school boards. The difficulty is due to the all-embracing nature of its subject matter and diversity of approaches and perspectives applied by its practitioners. More specifically, disagreements emerge among geography educationists over which specific geographical knowledge, skills and values should be included and at what stage of school education.

Every now and then, Indian geographers and educationists raise some pertinent issues concerning the development of geography in schools. Interestingly, the practice of school geography is differently problematised by them. This is in spite of the fact that the Central Board of Secondary Education (CBSE) considers a non-dualistic identity of geography in school curriculum, wherein both physical and human elements are taught (Kapur, 2004, p. 4189). There are those geographers and scholars who have Earth science-leaning criticise geography in school for its overwhelmingly "human" posture. They are at variance with the teaching of geography as a social science discipline and argue that geography should be taught as an Earth science discipline along with geology and environmental science (Kaur \& Chaudhri, 2003, pp. 618-619). On the contrary, geographers and scholars with social science background complain about geography's intimacy to physical sciences in schools. They are of the view that even though the spectrum of geography education in school encompasses physical, human, regional environmental geographies and maps, its overwhelming "physical" nature is quite explicit not only through its content but also through its ontological posture (Sunny, 2006, pp. 270-278).

The geography syllabus in Indian schools draws from both all three main branches of geography - regional, systematic, and practical geography (i.e. tools and techniques). Regional study deals with the teaching of the various regions of India and the world. Systematic geography textbooks focus on patterns of different natural and cultural phenomena and features without bothering about the underlying causes and processes which produce the existing patterns. Practical geography is concerned with tools, techniques and methods of collecting (field work), presenting (cartography) and analysing data (statistics). 
Despite the presence of both physical and human components of the Earth in geography syllabi, the treatment of these components has been rather lackadaisical. An examination of geography textbooks reveals that both physical and human elements of the Earth are mostly treated autonomously. The presentation of physical patterns and processes in geography rarely takes into account human factors. On the contrary, human elements of the Earth are treated independently of natural processes and features.

Though attempts were made to integrate physical and human components of the world in regional geography, many problems were associated with its teaching-learning (Kumar, 1996, pp. 246-253). The treatment of the subject was very encyclopaedic in form, with overemphasis on facts and figures about the geology, landforms, climate, populations, society, polity and economy of various regions of the world. Children were expected to cram facts and figures related to those regions. The presentation of lessons was also very uninteresting, boring, and therefore, the whole teaching-learning process was generally very dry and onerous.

Another problem associated with the geography syllabus has been no focus on the real lived-in experience of children. Yemuna Sunny (2008, p. 46), in her critical study of textbooks of various schools of the state of Madhya Pradesh, made following observations: "Geography curriculum largely consists of abstract and global themes like earth's movement, wind and pressure systems, ocean currents, etc. mostly in the initial grades of middle schools. The text is terse from junior to senior grades, its nature is uniform; concrete experiences are not engaged with in any form." Banerjee $(2006$, p. 287$)$ is of the view that a major challenge of school geography in India is that it is often perceived as a boring subject with focus on remembering the names of countries, capitals, rivers, hills, mountains, or which river comes from where and flowing where. It is considered useful for either general knowledge tests or to win in quizzes and helps in competitive exams for jobs.

The teaching-learning of geography in the secondary schools of India take place within the social science framework. The implications of teaching-learning of geography as a part of social sciences have been examined by many scholars (Alam, 2010, pp. 243-250; Basu et al., 2014, pp. 40-48; Solem \& Balachandran, 2014, pp. 7-16). In the context of this paper, two implications are worth noting. First, the geography syllabus does not entirely remain in the geographer's control. The syllabus is built for the entire social science and accordingly topics are allotted to geography. Second, the social science teachers, who may not be geography graduates, are usually reluctant to emphasize geography in their teaching.

The focus of the geography syllabus in India has been changing with time. Earlier regional geography constituted the most important part of the school geography syllabus, as the school geography syllabus contained the regional geography of the entire world. But with the implementation of the National Curriculum Framework (NCF) 2005, regional geography has been replaced by systematic geography. School geography has experienced many other changes in terms of syllabus and teaching methods. 


\section{RECENT I NI TI ATI VES}

The geography of the Earth is changing very fast and consequently the syllabus of school geography is also changing in terms of its contents and skills to uphold its relevance. Being a subject with ever-expanding boundaries, regular revision of syllabus to incorporate the emerging issues is a necessity. Moreover, recent innovations in educational philosophy and technology have also necessitated the revision of the geography syllabus. In the first decade of this century, wholesale changes have been made in the geography syllabus with regard to the selection of contents, skills, tools, techniques and values at various stages of school to keep pace with the disciplinary growth and changes in educational philosophy and methodology.

Table 1. Changing focus of the geography syllabus of National Council for Educational Research and Training (NCERT, 2005) textbooks

\begin{tabular}{|l|l|l|}
\hline \multicolumn{2}{|c|}{ Geography Syllabus of NCERT textbooks for secondary schools } \\
\hline \multicolumn{1}{|c|}{ Bases } & \multicolumn{1}{c|}{ 1990's } & \multicolumn{1}{c|}{ NCF $\mathbf{2 0 0 5}$} \\
\hline Scale of study & Global & National, regional and local \\
\hline Focus & Subject-centric & Child-centric \\
\hline Ideology & Realism & Constructivism \\
\hline $\begin{array}{l}\text { Location of } \\
\text { geography }\end{array}$ & Independent/autonomy & Less independent (integrated) \\
\hline Orientation & Discipline oriented & Theme oriented \\
\hline Learning & Textbook-centric & Activity-oriented \\
\hline
\end{tabular}

Source: The National Curriculum Framework, 2005

The National Curriculum Framework 2005 brought some profound changes in the way school geography should be practiced in India (Table 1). The NCF 2005 completely removed world regional geography from the school curricula. The new syllabus focuses on regional and local studies instead of on the global study. Further, prior to NCF 2005, the focus was on the subject but now the focus is on children. Earlier geography was taught on its own. Now it is taught as a part of social science along with history, political science, and economics. This aspect has important bearing on the school geography syllabus.

\section{OBJ ECTI VES OF THE STUDY}

The present study is about certain important issues concerning the status of the geography syllabus at secondary schools in India. The specific objectives of this paper are the following:

1. To analyse the changing focus of the geography syllabus in secondary schools of India; 
2. To find out the level of emphasis placed on various geographical themes, concepts, skills, emphasized in the geography syllabus at different levels of school education;

3. To identify topics from the geography syllabus most liked and disliked by students and teachers and to find out reasons for their liking/disliking those topics;

4. To find out the extent of association of certain academic skills and values with the geography discipline;

5. To identify the strengths and weaknesses of the geography syllabus.

\section{METHODS}

This paper has been developed with the help of data and information collected from three different sources. The first part of the paper draws upon documents prepared by the National Council for Educational Research and Training (NCERT, 2005), the apex body for curriculum development for schools in India, as well as on some recent studies by Indian geographers. In particular, the National Curriculum Framework 2005 is an important source information of this paper since all the geography textbooks and teaching resources, that are published by the NCERT and used by teachers and students today, are based on this document. The teaching pedagogy and evaluation techniques are also based on the NCF 2005. It is worth noting that the NCERT frames national curricular report and the NCF 2005 are the most recent curricular documents.

The paper also describes teachers' and students' perceptions of the geography syllabus. To map teachers' and students' perceptions, data has been collected by the author and his team for a University Grants Commission (UGC) - funded research project. Data have been obtained using a questionnaire-based survey of 170 geography teachers from as many secondary schools affiliated to 21 different school boards of India. The survey was conducted during the years 2013 and 2014. These schools were purposely selected mainly from the urban centres located in various geographical regions across several states in India. The overall aim of the survey was to ascertain the status of geography teaching across different school boards of India.

The third important source of data for this study is a questionnairebased survey of various school boards. To know the opinions of officials in charge of geography/social science about the geography syllabus, the survey was conducted in the year 2013-14 by the author. The questionnaire was sent to all the 34 school boards, however only ten boards responded. No significant change has occurred in the school curriculum in India since the publication of NCF 2005 and therefore the data and information on which this paper is based are still relevant and reflect the reality of geography teaching in schools. 


\section{RESULTS AND DISCUSSION}

\section{Themes of geography}

Ideally, the geography syllabus should include themes pertaining to all the major aspects of the subject - facts, concepts, skills, and values. The extent to which the various themes of geography are emphasized in the geography syllabus of different Indian schools is presented in Table 2. As it is obvious, geographical facts are strongly emphasized in the geography syllabus of six school boards, while moderately emphasized in three school boards. Geographical concepts are emphasized in the geography syllabus of seven school boards, while in two boards they are moderately emphasized. Geographical skills are strongly emphasized in four school boards, moderately emphasized in two school boards, while one board gives weak emphasis. One school board does not put any emphasis. Geographical values are not given much prominence in the geography syllabus of most school boards. Only two school boards strongly emphasized geographical values in their geography syllabus. Two school boards confer moderate emphasis, while one board bestow weak emphasis. One board give no emphasis. Thus, facts and concepts are given more prominence in the geography syllabus, while skills and values are given less prominence.

Table 2. Geographical themes emphasized in the geography syllabus at different school levels

\begin{tabular}{|l|r|r|r|r|}
\hline Geographical themes/ Number & \multicolumn{4}{|c|}{ Level of emphasis } \\
\cline { 2 - 5 } of school boards & Strong & Moderate & Weak & No emphasis \\
\hline Facts (9) & 6 & 3 & 0 & 0 \\
\hline Concepts (9) & 7 & 2 & 0 & 0 \\
\hline Skills (8) & 4 & 2 & 1 & 1 \\
\hline Values (8) & 2 & 5 & 1 & 0 \\
\hline
\end{tabular}

Source: Field Survey, 2013-14

\section{Geographical concepts}

Concepts are the building blocks of any disciplines. Some concepts are basic to the understanding of a discipline. These concepts are known as fundamental concepts. The concepts used to order, investigate, and understand phenomena are another aspect of domain knowledge in geography (Alaric, 2009, p. 374). Like other disciplines, there are certain concepts of geography which are of very fundamental value in the organization of the discipline. The extent to which various fundamental concepts have been emphasized in the teaching of geography in secondary schools is presented in Table 3.

As evident from the table, location is the most emphasized concept. Six school boards strongly emphasize, while three school boards moderately emphasize the concept of location in their curricula and textbooks. The concept of distance is strongly emphasized in five school boards but moderately emphasized in four school boards. The concept of direction is 
strongly emphasized in the curricula and textbooks of six school boards while moderately emphasized in three school boards. One school board gives no emphasis to the concept of direction. The concept of shape is strongly emphasized in the geography curriculum and textbooks of seven school boards, while moderately emphasized in two school boards. On the other hand, the concept of size is strongly, moderately and weakly emphasized in the curricula and textbooks of six, two and one school boards, respectively. The concepts of latitude and longitude are important in comprehending the Earth's surface. These concepts are strongly emphasized in the curricula and textbooks of seven school boards, while moderately emphasized in one school board each. One school board puts no emphasis on these concepts.

Table 3. Geographical concepts emphasized in the geography syllabus

\begin{tabular}{|c|c|c|c|c|}
\hline \multirow[t]{2}{*}{ Themes } & \multicolumn{4}{|c|}{ Level of emphasis } \\
\hline & Strong & Moderate & Weak & No emphasis \\
\hline Location & 6 & 3 & 0 & 0 \\
\hline Distance & 5 & 4 & 0 & 0 \\
\hline Direction & 6 & 3 & 0 & 1 \\
\hline Shape & 7 & 2 & 0 & 0 \\
\hline Size & 6 & 2 & 1 & 0 \\
\hline Latitude & 7 & 1 & 0 & 1 \\
\hline Longitude & 7 & 1 & 0 & 1 \\
\hline Space & 5 & 3 & 1 & 0 \\
\hline Place & 4 & 3 & 1 & 0 \\
\hline Areal differentiation & 2 & 5 & 0 & 1 \\
\hline Region & 4 & 3 & 0 & 1 \\
\hline Areal association & 3 & 4 & 0 & 1 \\
\hline People-environment relations & 7 & 2 & 0 & 0 \\
\hline Spatial interaction & 3 & 5 & 0 & 0 \\
\hline Spatial organization & 3 & 2 & 3 & 1 \\
\hline Spatial process & 3 & 3 & 2 & 1 \\
\hline Spatial pattern & 3 & 1 & 2 & \\
\hline Scale & 4 & 4 & 0 & 1 \\
\hline Map & 7 & 2 & 0 & 0 \\
\hline Globe & 7 & 2 & 0 & 0 \\
\hline Environment & 6 & 3 & 0 & 0 \\
\hline Geographical change & 4 & 4 & 1 & 0 \\
\hline
\end{tabular}

Source: Field Survey, 2013-14

Space and place are central organizing concepts of geography. Therefore, these concepts are strongly emphasized in the geography syllabus and textbooks of five (space) and four (place) school boards respectively, while three school boards moderately emphasized these concepts. Concepts of areal differentiation, areal association, spatial interaction and spatial organization, spatial pattern and processes are higher order concepts of geography. Therefore, these concepts are strongly emphasized by fewer school boards (two to three), but are moderately emphasized or weakly emphasized by most school boards in their syllabus. The concept of region is strongly emphasized by four school boards and moderately emphasized by three school boards in their syllabus. 
The study of people-environment relation is the most popular definition of geography. Therefore, this concept is strongly emphasized by seven school boards and moderately emphasized by two. Similarly, concepts of map and globe are popularly linked with the geography discipline. These concepts are given strong emphasis by seven school boards and moderate emphasis by two school boards each in their syllabus. The concept of scale and geographical change are offered strong emphasis by four school boards and moderate emphasis by an equal number of school boards. The concept of environment is given strong emphasis by six school boards and moderate emphasis by three. Thus, it is apparent that lower order concepts have stronger emphasis and higher order concepts have moderate or lower emphasis by school boards.

\section{Geographical skills}

One of the most distinguishing characteristics of geography is that it requires a distinct set of skills. Geographical skills may relate to asking geographical questions, acquiring, organizing, and analyzing geographical information, as well as answering geographical questions (Geography for Life, 1994). It was asked in the survey about the extent to which various skills have been emphasized in the teaching of geography as indicated in the school curriculum and geography textbooks (Table 4).

All these skills are given strong emphasis by four to five school boards in their textbooks and curricula. The skills related to asking geographical questions are given moderate emphasis by three school boards and no emphasis by two school boards. The skills pertaining to acquiring geographical information is given moderate emphasis by two school boards, weak emphasis by one school board, but no emphasis by two school boards. The skills related to organizing geographical information is given moderate and weak emphasis by two school boards each. The skills of analyzing geographical information are given moderate emphasis by only one school board and weak emphasis by three. The skills of answering geographical questions are given moderate and weak emphasis by two school boards each.

Table 4. Geographical skills emphasized in the geography syllabus at different levels of schools

\begin{tabular}{|l|r|r|r|r|}
\hline \multirow{2}{*}{ Skills } & \multicolumn{4}{c|}{ Level of emphasis } \\
\cline { 2 - 5 } & \multicolumn{1}{c|}{ Strong } & \multicolumn{1}{c|}{ Moderate } & Weak & No emphasis \\
\hline Asking geographical questions & 4 & 3 & 0 & 2 \\
\hline Acquiring geographical information & 4 & 2 & 1 & 2 \\
\hline Organizing geographical information & 5 & 2 & 2 & 0 \\
\hline Analyzing geographical information & 5 & 1 & 3 & 0 \\
\hline Answering geographical questions & 5 & 2 & 2 & 0 \\
\hline
\end{tabular}

Source: Field Survey, 2013-14 


\section{Extent of association of academic skills with geography}

Are certain academic skills distinctly geographical? An important component of geography as a discipline, both at the school and university levels, is the emphasis placed on learning a wide range of methods and skills, possibly wider than in any other subject (Alaric, 2009, p. 374). We asked officials of school boards/SCERT about the extent of association of various academic skills with geography. An analysis of their responses reveals the following pattern (Table 5).

Table 5. Extent of association of academic skills with geography

\begin{tabular}{|c|c|c|c|c|c|}
\hline \multirow[b]{2}{*}{ Academic skills } & \multicolumn{5}{|c|}{ Extent of association with geography } \\
\hline & $\begin{array}{l}\text { Exclusively } \\
\text { with } \\
\text { geography }\end{array}$ & $\begin{array}{l}\text { Mainly } \\
\text { with } \\
\text { geography }\end{array}$ & $\begin{array}{l}\text { Exclusively } \\
\text { with } \\
\text { subjects } \\
\text { other than } \\
\text { geography }\end{array}$ & $\begin{array}{l}\text { Mainly with } \\
\text { subjects } \\
\text { other than } \\
\text { geography }\end{array}$ & $\begin{array}{c}\text { All } \\
\text { subjects }\end{array}$ \\
\hline $\begin{array}{l}\text { Developing a sense of } \\
\text { space and distance }\end{array}$ & 2 & 2 & 0 & 2 & 3 \\
\hline $\begin{array}{l}\text { Observing, identifying, } \\
\text { recording, and } \\
\text { interpreting outdoor } \\
\text { data, scenes, and } \\
\text { landscapes }\end{array}$ & 1 & 3 & 1 & 1 & 3 \\
\hline Map making & 3 & 6 & 0 & 0 & 0 \\
\hline $\begin{array}{l}\text { Reading and } \\
\text { interpreting globes }\end{array}$ & 3 & 6 & 0 & 0 & 0 \\
\hline $\begin{array}{l}\text { Reading and } \\
\text { interpreting pictures }\end{array}$ & 1 & 4 & 0 & 0 & 2 \\
\hline $\begin{array}{l}\text { Making, reading, and } \\
\text { interpreting models } \\
\text { and graphical forms } \\
\text { such as sketches, } \\
\text { diagrams, graphs, } \\
\text { profiles, cross- } \\
\text { sections, and three- } \\
\text { dimensional } \\
\text { illustrations }\end{array}$ & 1 & 3 & 1 & 0 & 5 \\
\hline $\begin{array}{l}\text { Placing things in their } \\
\text { correct relative } \\
\text { positions }\end{array}$ & 1 & 4 & 0 & 1 & 3 \\
\hline $\begin{array}{l}\text { Scale - drawing things } \\
\text { that are approximately } \\
\text { proportional in size }\end{array}$ & 1 & 4 & 1 & 2 & 1 \\
\hline $\begin{array}{l}\text { Map reading and } \\
\text { interpreting - } \\
\text { visualizing in reality } \\
\text { what they see in } \\
\text { symbol from on paper }\end{array}$ & 3 & 5 & 0 & 0 & 1 \\
\hline
\end{tabular}

Source: Field Survey, 2013-14 
The skills pertaining to developing sense of space and distance are distinctly geographical. Understanding the concepts of space and distance are very much important to understand the Earth. Not surprisingly, school students are required to learn basic academic skills of making sense of space and distance in geography classes. These skills help students in placing and orienting themselves on the Earth. Two school boards officials associated this skill exclusively with geography, another two mainly with geography, while three with all school subjects. Appallingly, two school board officials linked this skill mainly with subjects other than geography. Perhaps, they themselves do not understand the true spirit of geography.

Observing, identifying, recording, and interpreting outdoor data, scenes and landscapes are traditionally associated with geography. These skills are associated exclusively with geography by one school board official, mainly with geography by three, one each exclusively with subjects other than geography and mainly with subjects other than geography. Three officials associated these skills with all subjects taught in schools.

Map making is the traditional skill acquired by geographers in their classrooms. Map-making is a specialized skill of cartography. It is associated exclusively with geography by three board officials and mainly with geography by six school board officials.

Being a replica of the Earth, reading and interpreting the globe is an important skill acquired by geographers. Reading and interpreting the globe is a specialized skill associated with geography, though other subjects can also teach these skills. These are associated exclusively with geography by three board officials and mainly with geography by six.

Similar to maps reading and interpreting, pictures are also important in geography. Geography is a visual science. Skills of reading and interpreting pictures are exclusively associated with geography by one board official, while they are associated mainly with geography by four. They are linked with all subjects by two board officials.

Making, reading, and interpreting models and graphical forms have strong roots in geography. Models and various graphical forms such as sketches, diagrams, graphs, profiles, cross-sections, and three-dimensional illustrations are taught by teachers of many subjects. Skills associated with making, reading, and interpreting models and graphical forms are exclusively associated with geography by one board official, while they are associated mainly with geography by three. One board official linked it exclusively with subjects other than geography.

Being a science of location and distribution, placing things in their correct relative positions is an important skill acquired by geography students. The skill of locating things on the Earth's surface is a basic skill acquired by all geography students. However, only one board official considers this skill exclusively with geography, while four officials considered it mainly with geography. One official linked this skill mainly with subjects other than geography, while three board officials considered this skill to be associated with all school subjects. 
Scale is the medium through which relations between map and the Earth can be comprehended. Drawings of objects that are proportional in size and shape facilitate geographical learning. The skill of drawing things according to proportion is linked exclusively with geography by one board official, while fourboard officials linked it mainly with geography. One board official linked it exclusively with subjects other than geography, while two officials linked it mainly with subjects other than geography.

Map reading and interpretation are basically processes of imagining the reality of the Earth by geographers, from maps. Three board officials linked this skill of map reading and interpretation exclusively with geography, while five of them linked it mainly with geography. Surprisingly, one teacher linked it with all subjects.

It is quite surprising to note that some board officials have id entified the study of scale exclusively with subjects other than geography. This is entirely incorrect. The correct answer could be any other for options other than the one he/she has chosen. Similarly, one board official respondent has opted for the location not specifically associating it with any other subject. The reality is that location is considered as the central organizing concept of geography. This kind of answers could be possible from teachers who lack basic understanding of geography. There are teachers teaching geography in schools despite the fact that they have not studied geography at graduation stage.

\section{Geographical values}

Geography is considered as a bridge between subjects of science and humanities. Therefore, the learning of geography imbibes certain values linked with both society and nature. The board officials were asked to indicate the extent to which various values have been emphasized in the teaching of geography as given in the school curriculum and geography textbooks. Their responses are given in Table 6 . The officials of five school boards considered the value of environmental and territorial justice to be strongly linked to geography, while three considered these to be moderately linked to geography. One official considered these to be weakly linked to geography.

Care for the environment is strongly associated with the teaching of geography according to eight board officials, while one of them considered this value to be moderately linked to geography. The value of resource conservation is strongly associated with geography by seven board officials, moderately and weakly linked to one each board officials. According to seven board officials, the value of global sense and interdependence is closely linked with geography, while for two these values are weakly linked to geography. Empathy for other cultures and lifestyles is also strongly linked with geography by five board officials, moderately and weakly associated with geography by three and one board official, respectively.

Unity in diversity and national integration are considered by seven board officials to have strong linkage with geography, and moderate and 
weak linkage with geography according to one official each. Preserving landscape quality is strongly associated with geography according to five board officials and moderately according to four officials.

Table 6. Extent of association of values with geography

\begin{tabular}{|l|r|r|r|r|}
\hline \multirow{2}{*}{ Values } & \multicolumn{3}{c|}{ Extent of association with geography } \\
\cline { 2 - 5 } & Strong & Moderate & Weak & No emphasis \\
\hline Justice - environmental and territorial & 5 & 3 & 1 & 0 \\
\hline Care for the environment & 8 & 1 & 0 & 0 \\
\hline Resource conservation & 7 & 1 & 1 & 0 \\
\hline Global sense and interdependence & 7 & 0 & 2 & 0 \\
\hline Em pathy for other cultures and lifestyles & 5 & 3 & 1 & 0 \\
\hline Unity and diversity of India & 7 & 1 & 1 & 0 \\
\hline National integration & 7 & 1 & 1 & 0 \\
\hline Preserving landscape quality & 5 & 4 & 0 & 1 \\
\hline Sustainability & 5 & 2 & 1 & 1 \\
\hline Aesthetic sense & 4 & 1 & 2 & \\
\hline
\end{tabular}

Source: Field Survey, 2013-14

The value of sustainability has been considered to have a strong association with geography by five board officials, moderate association by two and weak association by one official. One official is of the view that sustainability is not at all emphasized in the geography curriculum. Lastly, according to four board officials, acquisition of aesthetic sense is strongly emphasized in geography, moderately and weakly emphasized according to one and two officials, respectively. One official considered that this value is not at all emphasised in geography.

\section{Topics of the geography syllabus most liked and disliked by students}

In Table 7, there are topics and themes of geography most liked by students according to teachers' opinions. The most liked topics are from the sub-discipline of geomorphology as $23.5 \%$ of the teachers felt that topics from this sub-discipline are most liked by students. This is natural as geomorphic features and processes are visually appealing to students. Nearly $16 \%$ of the teachers were of the opinion that students liked topics pertaining to natural resources such as land, water, forests, fisheries and minerals. Some $11.8 \%$ of them felt that students liked topics of cartography, particularly maps. Ten percent of the teachers felt that students liked topics related to the environment and ecology, $8.2 \%$ liked topics related to atmosphere and climate, and $4.1 \%$ topics related to astronomy. Seven percent liked topics of regional geography of the world. By and large, compared to physical geography and cartography, likings for human geography is less. Only $7.1 \%$ of the teachers felt that students liked economic geography, $2.9 \%$ liked topics of human geography and $1.2 \%$ topics of cultural geography.

Two conclusions can be drawn from the above analysis. First, according to teachers, most students like to see geography as a part of physical sciences as it is obvious from their likings for geomorphology, 
climatology, ecology, and astronomy. Second, cartography, particularly maps, are also popular among students. This point clearly strengthens geography's long and intimate association with cartography.

When teachers were asked about reasons for liking a topic or theme, their answers were very much on the expected lines (Table 8). Over a quarter of the teachers (25.9\%) believed that students liked a topic when it was easier to understand. As much as $17.5 \%$ of the teachers felt that students liked a topic when it was interesting and $5.3 \%$ students liked a topic when it was relevant. Nearly one fourth of the teachers felt students liked a topic when the topic was interesting, easy to understand and relevant. $18.2 \%$ of the teachers felt that students liked a topic when it was interesting and easy to understand, while $3.5 \%$ liked it when the topic was both interesting and relevant.

Table 7. Most liked topic of the geography syllabus in various school boards

\begin{tabular}{|l|r|r|}
\hline \multicolumn{1}{|c|}{ Topic } & \multicolumn{1}{|c|}{ Total } & Percentage \\
\hline No response & 8 & 4.7 \\
\hline Any topics & 3 & 1.8 \\
\hline Astronomy & 7 & 4.1 \\
\hline Cartography & 20 & 11.8 \\
\hline Climate \& atmosphere & 14 & 8.2 \\
\hline Cultural geography & 2 & 1.2 \\
\hline Ecology \& environmental issues & 17 & 10.0 \\
\hline Economic geography & 12 & 7.1 \\
\hline Geom orphology & 40 & 23.5 \\
\hline Human geography & 5 & 2.9 \\
\hline Natural disaster & 2 & 1.2 \\
\hline Natural resources & 27 & 15.9 \\
\hline Regional geography & 13 & 7.6 \\
\hline Total & $\mathbf{1 7 0}$ & $\mathbf{1 0 0}$ \\
\hline
\end{tabular}

Source: Field Survey, 2013-14

Table 8. Reasons for liking a topic by students

\begin{tabular}{|l|r|r|}
\hline \multicolumn{1}{|c|}{ Reasons for liking a topic } & Number of teachers & \multicolumn{1}{c|}{ Percentage } \\
\hline No response & 8 & 4.7 \\
\hline Interesting & 29 & 17.1 \\
\hline Easy to understand & 44 & 25.9 \\
\hline Relevant & 9 & 5.3 \\
\hline Interesting, easy to understand \& relevant & 42 & 24.7 \\
\hline Interesting \& easy to understand & 31 & 18.2 \\
\hline Easy to understand \& relevant & 1 & 0.6 \\
\hline Interesting \& relevant & 6 & 3.5 \\
\hline Total & $\mathbf{1 7 0}$ & $\mathbf{1 0 0}$ \\
\hline
\end{tabular}

Source: Field Survey, 2013-14

In Table 9, there are presented topics and themes of geography, which are most disliked by students according to the teachers' opinions. Nearly one quarter $(23.5 \%)$ of the teachers did not mention the topics most disliked by students. In the opinion of $17.1 \%$ the teachers, the most disliked topics by 
students are related to natural resources, followed by cartography $(14.1 \%)$, and climate and atmosphere (12.9\%). It could be due to students' difficulties in understanding the concepts of these sub-disciplines. As much as $7.6 \%$ of the teachers felt that students did not like topics of economic geography. It could be because of overemphasizing data which are often presented in tables and diagrams in geography books in economic geography. A good proportion of teachers felt that students did not like topics of geomorphology ( $8.2 \%)$ and regional geography $(8.2 \%)$.

Table 9. Most disliked topics and themes of geography by students

\begin{tabular}{|l|r|r|}
\hline \multicolumn{1}{|c|}{ Topics } & Teachers & \multicolumn{1}{|c|}{ Percentage } \\
\hline No response & 40 & 23.5 \\
\hline Astronomy & 2 & 1.2 \\
\hline Cartography & 24 & 14.1 \\
\hline Climate \& atmosphere & 22 & 12.9 \\
\hline Ecology \& environmental issues & 2 & 1.2 \\
\hline Economic geography & 13 & 7.6 \\
\hline Geom orphology & 14 & 8.2 \\
\hline Human geography & 5 & 2.9 \\
\hline Hydrology & 2 & 1.2 \\
\hline Natural disaster & 1 & 0.6 \\
\hline Natural resources & 29 & 17.1 \\
\hline Regional geography & 14 & 8.2 \\
\hline Others & 2 & 1.2 \\
\hline Total & $\mathbf{1 7 0}$ & $\mathbf{1 0 0}$ \\
\hline
\end{tabular}

Source: Field Survey, 2013-14

Teachers gave many reasons why students did not like some topics (Table $10)$. About one fourth $(23.5 \%)$ of the teachers did not answer this question. The most important reason given for not liking a particular topic is difficulty in understanding that topic. The difficulty could be due to poor presentation of the topic in books, poor teaching or unsuitability of topics for students of a particular grade. As high as $21.8 \%$ teachers felt that dry and boring presentation of topics (loads of data and facts) are reasons for students' disliking a topic. On the other hand, $12.9 \%$ teachers considered both difficulties in understanding a topic, as well as the boring and dry nature of the topic, as reasons for disliking the topic. Another reason for disliking a topic was the lack of relevance of the topic.

Table 10. Reasons for disliking a geographical topic

\begin{tabular}{|l|r|r|}
\hline \multicolumn{1}{|c|}{ Reasons for disliking a topic/ theme } & Number of teachers & Percentage \\
\hline No response & 40 & 23.5 \\
\hline Dry and boring & 37 & 21.8 \\
\hline Difficult to understand & 54 & 31.8 \\
\hline Not relevant & 2 & 1.2 \\
\hline Other & 3 & 1.8 \\
\hline Dry / boring, difficult to understand \& not relevant & 5 & 2.9 \\
\hline Dry / boring \& difficult to understand & 22 & 12.9 \\
\hline Difficult to understand \& not relevant & 5 & 2.9 \\
\hline Dry / boring \& not relevant & 2 & 1.2 \\
\hline Total & $\mathbf{1 7 0}$ & $\mathbf{1 0 0}$ \\
\hline
\end{tabular}

Source: Field Survey, 2013-14 


\section{Favourite and difficult topics of geography syllabus for teachers}

The topics and themes which the teachers find difficult to teach are presented in Table 11 . More than half (51.2\%) of the teachers did not name the topics which they found difficult to teach. The most difficult topics identified by geography teachers belonged to the sub-disciplines of physical geography (e.g. climate and atmosphere - 10\%, geomorphology $-8.2 \%$, and hydrology $-2.4 \%$ ). The next difficult topics to teach are from the subdiscipline of cartography, with $9.4 \%$ of teachers finding cartog raphy topics difficult to teach. On the human side, the most difficult sub-discipline is economic geography. Over seven percent of the teachers find topics of economic geography difficult to teach.

Table 11. Topics of the geography syllabus that teachers find most difficult to teach

\begin{tabular}{|l|r|r|}
\hline \multicolumn{1}{|c|}{ Topics } & \multicolumn{1}{c|}{ Total } & \multicolumn{1}{c|}{ Percentage } \\
\hline No response & 87 & 51.2 \\
\hline Astronomy & 2 & 1.2 \\
\hline Cartography & 16 & 9.4 \\
\hline Climate \& atmosphere & 17 & 10.0 \\
\hline Geographical concepts & 1 & 0.6 \\
\hline Ecology \& environmental issues & 2 & 1.2 \\
\hline Economic geography & 12 & 7.1 \\
\hline Geomorphology & 14 & 8.2 \\
\hline Human geography & 3 & 1.8 \\
\hline Hydrology & 4 & 2.4 \\
\hline Natural resources & 4 & 2.4 \\
\hline Regional geography & 6 & 3.5 \\
\hline Others & 2 & 1.2 \\
\hline Total & $\mathbf{1 7 0}$ & $\mathbf{1 0 0}$ \\
\hline
\end{tabular}

Source: Field Survey, 2013-14

In Table 12, reasons for difficulties in teaching a topic or a theme by teachers are presented. Over half $(51.8 \%)$ of the teachers did not answer this question. The rest of teachers gave various reasons why they found a topic difficult to teach. The most important reason was lack of proper teaching resources. As much as $11.8 \%$ of the teachers identified this as a reason for the poor teaching of a topic. About seven percent of the teachers identified lack of training for finding it difficult to teach a topic, while $4.1 \%$ blamed the lack of latest information.

Many teachers identified multiple reasons for difficulty in teaching a topic. Over $10 \%$ of the teachers blamed both lack of training and lack of teaching resources as reasons for finding difficult to teach a subject. On the other hand, $7.6 \%$ of the teachers experienced both the absence of teaching resources, as well as the lack of latest information on a topic as reasons for experiencing difficulties in teaching a topic or theme. Nearly three percent 
of the teachers blamed lack of training and latest information as reasons for experiencing difficulties in teaching a topic.

Table 12. Reasons for difficulties in teaching a topic, according to teachers

\begin{tabular}{|l|r|r|}
\hline Reason of difficulties & No. of teachers & Percentage \\
\hline No response & 88 & 51.8 \\
\hline Lack of training & 12 & 7.1 \\
\hline Lack of teaching resources & 20 & 11.8 \\
\hline Lack of latest inform ation & 7 & 4.1 \\
\hline $\begin{array}{l}\text { Lack of training, lack of teaching resources and latest } \\
\text { inform ation }\end{array}$ & 4 & 2.4 \\
\hline Lack of training \& lack of teaching resources & 18 & 10.6 \\
\hline Lack of teaching resources \& lack of latest inform ation & 13 & 7.6 \\
\hline Lack of training \& lack of latest information & 5 & 2.9 \\
\hline Any other & 3 & 1.8 \\
\hline Total & $\mathbf{1 7 0}$ & $\mathbf{1 0 0}$ \\
\hline
\end{tabular}

Source: Field Survey, 2013-14

Table 13. Most favourite topic of the teachers

\begin{tabular}{|l|r|r|}
\hline Topics & Number of teachers & Percentage \\
\hline No response & 29 & 17.1 \\
\hline All topics & 8 & 4.7 \\
\hline Astronomy & 5 & 2.9 \\
\hline Cartography & 16 & 9.4 \\
\hline Climate \& atmosphere & 13 & 7.6 \\
\hline Ecology \& environmental issues & 7 & 4.1 \\
\hline Economic geography & 22 & 12.9 \\
\hline Field trips & 2 & 1.2 \\
\hline Geom orphology & 31 & 18.2 \\
\hline Human geography & 4 & 2.4 \\
\hline Natural disasters & 5 & 2.9 \\
\hline Natural resources & 16 & 9.4 \\
\hline Regional geography & 12 & 7.1 \\
\hline Total & $\mathbf{1 7 0}$ & $\mathbf{1 0 0}$ \\
\hline
\end{tabular}

Source: Field Survey, 2013-14

Every teacher may have favourite topics which they like to teach. Their responses regarding this issue are presented in Table 13. Here, most teachers have identified themes from physical geography as their most favourite teaching topics (geomorphology - 18.2\%; climate and atmosphere - 7.6\%; ecology and environment - 4.1\%). Among human aspects, the most favourite topics identified by teachers are from economic geography $(12.9 \%)$, followed by natural resources (7.6\%). A higher proportion $(9.4 \%)$ of teachers identified cartography as their most favourite topic of teaching. Regional geography themes are popular among $7.1 \%$ teachers. The popularity of physical geographical themes could be due to their inherent qualities. Cartography could be a favourite topic because of the artistic skills it requires, like map making. Economic geography and natural resources may be favourite because of their influence in our day-to-day life. 


\section{Strengths and weaknesses of the current geography syllabus}

The question posed to teachers to know the strengths and weaknesses of the geography syllabus was an open ended one. Therefore, the opinions of teachers varied considerably. Their opinions have been clubbed based on similarities. The positive points of the current syllabus of geography are given in Table 14.

Table 14. Strengths of the current geography syllabus

\begin{tabular}{|l|r|r|}
\hline \multicolumn{1}{|c|}{ Positive points of the current syllabus } & $\begin{array}{c}\text { No. of } \\
\text { teachers }\end{array}$ & Percentage \\
\hline No answer & 97 & 57.1 \\
\hline Practical subject & 3 & 1.8 \\
\hline Learners grasp the geographical views of our nation & 3 & 1.8 \\
\hline Feel good, comforting, interesting & 3 & 10.6 \\
\hline Including new technologies (e.g. GIS, GPS \& RS) & 6 & 1.8 \\
\hline Updated syllabus every year & 13 & 3.5 \\
\hline $\begin{array}{l}\text { It creates awareness to save our Earth and stop the } \\
\text { degradation of nature and environment; interlinked or } \\
\text { interrelated with environmental study }\end{array}$ & & 7.8 \\
\hline Overem phasis on topics on India geography & 4 & 2.4 \\
\hline Various cultures of India have been included & 1 & 0.6 \\
\hline Misprinting/ wrong printing & 1 & 0.6 \\
\hline More or less based on the NCERT & 1 & 0.6 \\
\hline Government supported & 1 & 0.6 \\
\hline New geographical topics included & 4 & 2.4 \\
\hline Em phasis on project work \& geographical facts & 2 & 1.2 \\
\hline Less reading materials for students & 2 & 1.2 \\
\hline The subject is very much dynamic & 2 & 1.2 \\
\hline Discussion of physical, environmental \& Indian geography & 2 & 1.2 \\
\hline Too many facts oriented course & 2 & 1.2 \\
\hline Too vast & 1 & 0.6 \\
\hline Focus on human resources should benefit student \& society & 1 & 0.6 \\
\hline Creating awareness about globalization & 1 & 0.6 \\
\hline Better scope for higher study \& job & 1 & 0.6 \\
\hline Geography has plenty of pictures \& diagrams to understand \\
topics & 1 & 0.6 \\
\hline Total & $\mathbf{1 7 0}$ & $\mathbf{1 0 0}$ \\
\hline SOurce: Fied Survey, $2013-14$ & & \\
\hline
\end{tabular}

Source: Field Survey, 2013-14

A very high proportion of teachers (57.1\%) did not answer this question. They had no opinion on this. For $10.6 \%$ of the teachers, the syllabus is good and comfortable. Some other positive aspects of the geography syllabi identified by geography teachers are the following: the syllabus is updated regularly $(3.5 \%)$; emphasis on practical $(1.8 \%)$; emphasis on awareness about the Earth, new geographical topics included $(2.4 \%)$; focus on environment and nature $(7.8 \%)$; present geographical view of nation 
$(1.8 \%)$; dynamic subject $(1.8 \%)$, etc. Thus, geography acquires its strength as an interesting subject and it emphasizes on environmental awareness.

In Table 15, the weaknesses of the current syllabus of geography are presented. Exactly $50 \%$ of the respondents did not answer this question. According to $5.3 \%$ of the teachers, there is no weakness of the current syllabus. Seven percent of the teachers consider geography syllabi to be outdated.

Table 15. Weaknesses of the current geography syllabus

\begin{tabular}{|c|c|c|}
\hline Weaknesses of the current syllabus & No. of teachers & Percentage \\
\hline No answer & 85 & 50.0 \\
\hline No problem as such & 9 & 5.3 \\
\hline Exclusion of world geography & 10 & 5.9 \\
\hline Outdated, lack of current issues & 7 & 4.1 \\
\hline Practical work does not start from the $6^{\text {th }}$ grade & 2 & 1.2 \\
\hline $\begin{array}{l}\text { Presentation in books is not good (dull, bo ring, too } \\
\text { much data, unattractive for students, lack of detail } \\
\text { explanation, no figures for certain topics, mistakes in } \\
\text { basic facts) }\end{array}$ & 12 & 9.5 \\
\hline Vast and eclectic syllabus & 14 & 8.8 \\
\hline Overemphasis on environmental issues & 1 & 0.6 \\
\hline Lack of information about the states of India & 2 & 1.2 \\
\hline Overemphasis on themes of resource & 2 & 1.2 \\
\hline Lack of information on environmental issues & 2 & 1.2 \\
\hline Teaching of geography with social science & 1 & 0.6 \\
\hline Lack of map-based questions in board exams & 1 & 0.6 \\
\hline Lack of continuity and latest techniques & 2 & 1.2 \\
\hline Geography teaching is not compulsory & 1 & 0.6 \\
\hline $\begin{array}{l}\text { More focus on general knowledge \& environmental } \\
\text { issues }\end{array}$ & 1 & 0.6 \\
\hline Lack of comprehensive knowledge & 3 & 1.8 \\
\hline Neglect of physical geography & 1 & 0.6 \\
\hline $\begin{array}{l}\text { Neglect of rem ote sensing, GIS, cartography \& } \\
\text { com puter technologies }\end{array}$ & 3 & 1.8 \\
\hline No linkage with astrology & 1 & 0.6 \\
\hline $\begin{array}{l}\text { Lack contemporary issues (e.g. population, } \\
\text { development, poverty \& corruption) }\end{array}$ & 1 & 0.6 \\
\hline Repetition of topics & 4 & 2.4 \\
\hline Lack of teaching resources & 1 & 0.6 \\
\hline No emphasis on practical approach & 1 & 0.6 \\
\hline Too much of project/activity work & 1 & 0.6 \\
\hline Total & 170 & 100 \\
\hline
\end{tabular}

Source: Field Survey, 2013-14

As many as $6.5 \%$ of the teachers felt that the geography books based on current syllabus were not good (dullness, lack of detail explanation, lack of figures). As much as $8.8 \%$ of the teachers felt that the syllabus of geography was very vast and eclectic. Three teachers considered that the teaching of geography lacked proper explanation. Another three teachers felt that the latest geographical technologies were not included in the syllabus and there was repetitiveness in syllabus content of geography for various classes. 


\section{CONCLUSIONS}

The study suggests facts and concepts are given more prominence in the geography syllabus, while skills and values are given less. It also indicates that skills associated with maps and globes are strongly linked to geography. Further, values associated with environment, resources and global interdependence have strong linkage with geography. According to teachers, a large proportion of students see geography as a part of natural sciences. This is clearly evident from their likings for topics and theme of geomorphology, climatology, ecology, and astronomy. Considering teachers' opinions, cartography, particularly map and map related activities, are quite popular among students. This point clearly strengthens geography's historical and intimate association with cartography. Two major strengths of the current geography syllabus identified by teachers are that the topics are interesting and create awareness about the environment. Two major weaknesses of the geography syllabus as identified by schoolteachers are the exclusion of world geography and lack of regular up gradation of the syllabus. Further, physical and human elements are taught separately.

Being an integrative subject, the hallmark of geography is regional synthesis. If geographers do not provide the synthesis of phenomena in parts of the Earth's space, who else would? (Gosal, 1999, p. 2). The real educational value of geography can only be realized when the subject is taught in such a way that the elements of both physical and social sciences are studied within the regional framework. In the era of globalization, local events may be caused by global processes and global processes, in turn, may be influenced by local events. Therefore, there should be more focus on the study of the regional geography of the world in the geography syllabus.

\section{ACKNOWLEDGMENTS}

The author thankfully acknowledges the University Grants Commission, New Delhi, for financial assistance to the research project.

\section{References}

Alam, S. (2010). Recent Trends in School Geography in India. Journal of Geography, 109(6), 243-250.

Alaric, M. (2009). Re-centering Geography: A School-based Perspective on the Nature of the Discipline. Geographical Research, 47(4), 368-379.

Banerjee, B.K. (2006). Geography Education in Indian Schools. Internationale Schulbuchforschung, 28, 283-292. 
Basu, P., Pawson, E., Akhter, M., Palmer, D., \& Mervine, V.M. (2014). Connecting High School and University Teachers in National and International Contexts: Perspectives from the 2012 Bangalore Workshop of the AAG-CGGE. Journal of Geography in Higher Education, 38(1), 40-48.

Geography and You (2014). Colloquium Report: Rethinking Geography Education and Research in India. Retrieved 8 October 2020, from https://geographyandyou.com/colloquium-report-rethinking-geographyeducation-and-research-in-india/

Geography Education Standards Project (1994). Geography for Life: National Geography Standards 1994. Washington DC: National Geographic Society.

Gosal, G.S. (1999). Fourth Survey of Research in Geography in India: An Overview. In Gosal, G.S. (ed.), Fourth Survey of Research in Geography 1976-1982 (pp. 1-7). New Delhi: Manak Publications Pvt. Ltd.

Kapur, A. (2004). Geography in India: A Languishing Social Science. Economic and Political Weekly, 39(11), 4187-4195.

Kaur, P. \& Chaudhri, N. (2003). The Status of Geoscience Education in School Curriculum. Current Science, 84(5), 618-619.

Kumar, P. (1996). Teaching-Learning Process in Geography. In Singh, L.R. (ed.), New Frontiers in Indian Geography (pp. 246-253). Allahabad, India: R.N. Dubey Foundation.

Long, M. \& Roberson, B.S. (1966). Teaching Geography. London: Heinemann Educational Books Ltd.

National Council for Educational Research and Training (2005). National Curriculum Framework 2005. New Delhi: National Council for Educational Research and Training.

Solem, M. \& Balachandran, C.S. (2014). Internationalizing Geography Education: A Focus on India. Journal of Geography in Higher Education, 38(1), 7-16.

Sunny, Y. (2006). Analysing Current Practices in Geography Education. Economic and Political Weekly, 41(3), 217-278.

Sunny, Y. (2008). Experience and Science in Geography Education. Economic and Political Weekly, 43(24), 45-49. 